\title{
Role of Flavonoids in DNA Damage and Carcinogenesis Prevention
}

\author{
Prabha Tiwari ${ }^{1^{*}}$ and Mishra ${ }^{2}$
}

${ }^{1}$ National Institutes of Biomedical Innovation Health and Nutrition, 7-6-8, Saito Asagi, Ibaraki, Osaka 567-0085, Japan

${ }^{2}$ BM International Research Center, Jain Vishwa Bharati Institute (Deemed University), Ladun, Rajastan, India

*Corresponding author: Prabha Tiwari, National Institutes of Biomedical Innovation Health and Nutrition, 7-6-8, Saito Asagi, Ibaraki, Osaka 567-0085, Japan, Tel: +819096944822; E-mail: prabha_bt@rediffmail.com

Received date: June 5, 2017; Accepted date: June 16, 2017; Published date: June 20, 2017

Copyright: (C) 2017 Tiwari P, et al. This is an open-access article distributed under the terms of the Creative Commons Attribution License, which permits unrestricted use, distribution, and reproduction in any medium, provided the original author and source are credited.

\section{Abstract}

High level of ionizing radiation and various other mutagenic agents can damage DNA and induce carcinogenesis which may be transferred to offspring's. Flavonoids are major antioxidant compounds obtained from plants and form a significant proportion of most diets. In this review, we have summarized the present understanding of the roles of various flavonoids as preventive approaches against DNA damage and carcinogenesis.

Keywords: Antioxidant; DNA damage; Flavonoid; Mutagenesis

\section{Introduction}

In living cells, free radical species derived from oxygen (ROS) and nitrogen (NOS) are produced endogenously by mitochondria, cytochrome $\mathrm{P} 450$ and peroxisome, which act as signaling molecules and control metabolic pathways and the cell cycle [1]. Usually, cells have their defense mechanisms such as antioxidant enzymes catalase and superoxide dismutase and free radical scavengers like glutathione (GSH) for the removal of free radicals. However under stress conditions such as exposure to radiation or chemicals, this balance is disturbed and excessive free radicals are generated that cannot be cleared by natural defenses and can lead to DNA damage and carcinogenesis.

Many factors are known to cause DNA damage. Ionizing radiation is one of the main DNA damaging and carcinogenic agents. Radiation induced DNA damage signaling and repair pathways play important role in mutagenesis and carcinogenesis. Other major DNA damaging agents are cigarette smoke, chemical carcinogens and food borne carcinogens.

DNA damage includes various types of lesions ranging from isolated base lesions or single strand breaks (SSBs) to complex lesions like double strand breaks (DSBs) and other non-DSB such as oxidatively generated clustered DNA lesions (OCDLs) [2]. DNA damage and inefficient repair are known to cause cellular injury and initiate the process of carcinogenesis.

Various types of natural compounds are used in cancer prevention and cancer therapy [3]. Recent studies have explored the potential of flavonoids obtained from food sources in the prevention of various oxidative stress induced diseases such as cancer and cardiovascular diseases. Flavonoids regulate many cellular, biochemical and immunological events involved in cancer initiation and progress [4]. A number of studies have demonstrated ability of flavonoids to protect cellular DNA against damage [5].

Many molecular biology methods such as TUNEL assay, Flow and laser scanning cytometry, Nick translation and electron microscopy are used to detect DNA strand breaks [6]. Two different types of strategies categorized as direct and indirect methods are used to measure radiation-induced DNA damage [7]. The most commonly used indirect methods to visualize the DNA damaging protective effects of flavonoids are micronuclei formation and comet assay, which can measure biological consequences of DNA damage. Also, calf thymus DNA and plasmid pBR322 DNA is commonly used to study protective effects of flavonoids. Many studies have also linked protective action of flavonoids with their anti-oxidant nature or ability to regulate cell signaling [8].

In this review we have focused on summarizing the current understanding of the mechanisms of action of widely used flavonoids to explore their potential use in the prevention of DNA damage and carcinogenesis.

\section{DNA Damage Inducing Agents and Biological Responses}

DNA can be modified and damaged by various endogenous and exogenous factors. Common endogenous factors include Reactive Oxygen Species (ROS) and Reactive Nitrogen Species (RNS) generated during normal metabolic functions, errors during DNA replication and spontaneous or enzymatic conversions

A major exogenous or environmental factor is ionizing-radiation which can induce the formation of DSBs. Other exogenous factors include non-ionizing ultraviolet radiation through biochemical modifications and chemical compounds such as cisplatin, benzo[a]pyrenes $(\mathrm{BaP})$, nitrogen mustards, methyl methanesulphonate (MMS), N-nitroso-N-methylurea (NMU) and N-ethyl-N-nitrosourea (ENU) [9]. Tobacco products and chemical found in food such as aflatoxins found in contaminated peanuts and heterocyclic amines in over-cooked meats are also classified as cancer-causing DNAdamaging agents [10]. Chemicals bind directly to DNA and induce damage by forming DNA adduct [11]. Cells have evolved many pathways to cope up with the harmful effects of DNA damage which are classified as 'DNA repair' or 'DNA damage tolerance' (DDT) [12]. In mammalian cells two main pathways, namely non-homologous end joining (NHEJ), which is major pathway and homologous recombination and which, provides greater repair fidelity are involved in DSBs repair [13]. In the case of single-stranded DNA lesions, DNA 
damage tolerance (DDT) pathway is involved, which promotes the bypass of single-stranded DNA lesions encountered by DNA polymerases during DNA replication [14]. If the DNA damage is not repaired properly it can lead to mutations and eventually carcinogenesis.

\section{Flavonoids in Food Sources and Their Role in Prevention of Diseases}

Flavonoids are secondary metabolites of plants that impart coloration to most flowers, fruits and seeds [15]. Flavonoids have a common structure of two aromatic rings connected to three carbon atoms. In addition, the basic structure of flavonoids allows multiple substitution patterns in benzene rings (Figure 1). Flavonoids are therefore, classified based on their chemical structure $[16,17]$.

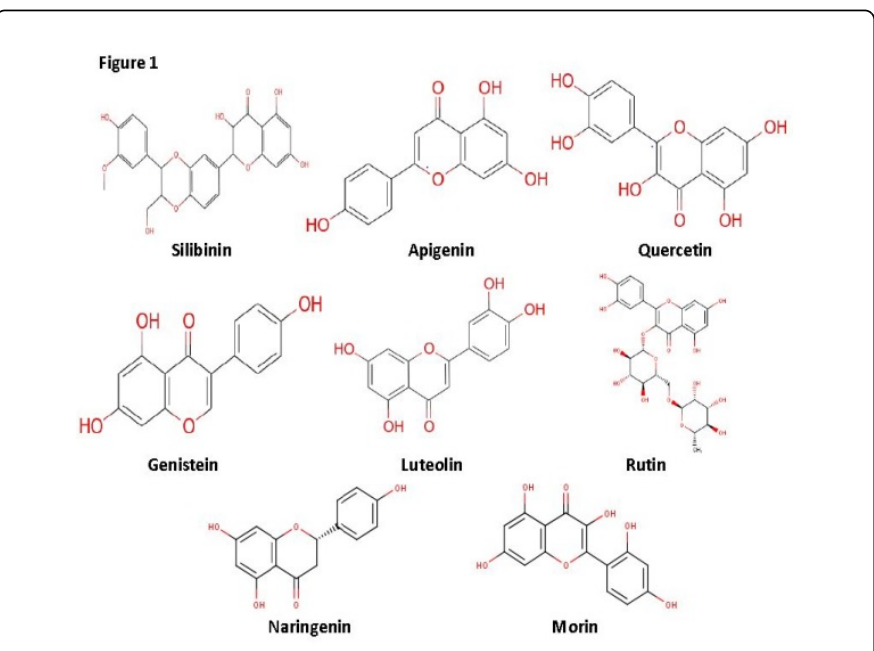

Figure 1: Chemical structure of the key flavonoids with preventive activities against DNA damage and carcinogenesis.

Few epidemiological studies have been performed to understand the health benefits of flavonoids. Flavonoids are majorly found in daily diet. Epidemiological study using smokers who ingested flavonoid rich food was performed and suggested that flavonoids protected against harmful effects of tobacco carcinogen in bladder mucosal cells [18]. To elucidate the possible roles of dietary flavonoids in cancer and the prevention of cardiovascular diseases number of cohort studies and one cross-cultural study was performed. Protective role of flavonoids in cardiovascular disease was found in few studies while reduction in lung cancer was observed only in one study [19]. Flavonoid intake was linked with lower cardiovascular disease mortality [20]. A number of studies have been performed to study protective effect of flavonoids against cancer [21]. Flavonoids showed beneficial effect in the treatment of hemorrhoidectomy with radiofrequency scalpel by reducing post-hemorrhoidectomy symptoms [22]. Many health benefits of flavonoids in food have been suggested but in general it is difficult to conclude because flavonoids are modified in different ways in mammalian biology.

Due to an improved understanding of the isolation and identification of flavonoid compounds from different food sources, it has become easier to understand health benefits of individual compounds. Flavonoids are found abundantly in vegetables and fruits and have shown many health benefits in both in vitro and in vivo studies [23,24]. Many species of plants have evolved flavonoids as a protective mechanism against harmful effects of ultraviolet-B radiation [25]. Zea mays plant, which contain flavonoids anthocyanins showed protection from UV- radiation-induced DNA [26].

\section{Antioxidant and Pro-Oxidant Behavior of Flavonoids}

Among various polyphenols used in human diet, flavonoids are most abundant. They are obtained from plant sources and have shown important health benefits. They show antioxidant properties and studies to understand their roles in various diseases have been undertaken. However they also show prooxidant activity $[27,28]$ and can lead to DNA damage and mutagenic effects. Flavonoids have shown both mutagenic and anti-mutagenic properties [29]. Few plant flavonoids have been assayed for mutagenicity and their mutagenic activities were correlated with the flavonoid content [30]. Further mutagenic activities of flavonoids were correlated with their structure [31]. Ames test has been widely used to screen mutagenic potential of various flavonoids. Hydroxylation pattern and presence of metabolic activation are important determinants of the mutagenic activities of flavonoids; this was suggested by using Ames test in Salmonella typhimurium strains [32]. Several flavonoids such as Catechins [33], flavonoids of propolis [34] can induce oxidative DNA damage through the generation of reactive oxygen species (ROS). Dietary flavonoids such as quercetin, luteolin and genistein, reduced oxidative DNA damage through inhibition of ROS [35]. Further the protection of DNA from oxidative damage and pro-oxidative effects was shown to depend on flavonoid concentration and the incubation period [36].

\section{Interaction of Flavonoids with DNA}

It has been proposed that flavonoids can form complexes with DNA and protect it against oxidative damage. The antioxidation potential of antioxidants are related to their binding modes to the DNA duplex [37]. Cumulative studies have suggested that flavonoids can interact with DNA; FTIR and UV-Visible difference spectroscopic methods have been used to study the interactions of flavonoids quercetin, kaempferol, and delphinidin with DNA at molecular level and found that delphinidin induces more stabilizing effect on DNA duplex than quercetin and kaempferol [38]. The interactions of flavonoids, such as quercetin, kaempferide and luteolin, with fish sperm DNA were also reported [39]. Flavonoids such as hesperitin and naringenin interacted with calf thymus DNA and stabilized it [40].

Recently it was reported that flavonoid Quercetin can interact with human telomerase sequences and stabilizes the G-quadruplex structure [41].

\section{DNA damage prevention by flavonoids with implications to carcinogenesis prevention}

Silibinin: Flavonoids have shown promising results both in the inhibition of initiation and progression of cancer. DNA damage protective properties of flavonoids are well reported. We previously reported radioprotective and anti-cancer properties of flavonoid Silibinin, a major active component of Silymarin which is obtained from milk thistle [42-44]. Silibinin protected human lymphocytes against gamma-radiation induced DNA damage and micronuclei formation.

Silibinin also protected plasmid pBR322 DNA and mice leukocytes DNA against gamma-radiation-induced damage [44], Cancer 
chemopreventive nature of Silibinin was also attributed to its ability to inhibit both cell growth and DNA synthesis [45]. Silibinin inhibits UVB-tumor initiation, promotion and carcinogenesis in SKH-1 hairless mouse skin [46]. Silibinin accelerated the repair of cyclobutane pyrimidine dimers (CPD) induced by UVB radiation JB6 mouse epidermal cells and SKH1 hairless mice. Silibinin protected against UVB-induced photodamage by upregulating p53-mediated GADD45a signaling (Roy S, Carcinogenesis, 2012). Further investigation showed that silibinin also induced endogenous IL-12 to protect against UVBcaused skin damages [47]. Silibinin also inhibited carcinogen azoxymethane and 1,2-dimethylhydrazine induced initiation and progression of colon cancer [48-50] and spontaneous intestinal tumorigenesis [51,52].

Apigenin: Apigenin is a natural flavonoid found in many plants and has shown promising results in chemotherapy [53,54]. Apiginin has also shown cancer preventive and DNA damage protective properties. For instance, Apigenin inhibited skin carcinogenesis initiated by 7,12 dimethylbenz(a)anthracene (DMBA) and promoted by 12-Otetradecanoylphorbol-13-acetate (TPA) by inhibition of epidermal ornithine decarboxylase induction [55]. UVA/B induced skin carcinogenesis was also inhibited by Apigenin (Brit DF, 1997). Apigenin stimulated Nucleotide excision repair genes and protected against UV-B induced DNA damage in HaCaT skin keratinocytes and animal models [56]. Furthermore, it was found that that apigenin can preferentially accumulate in the nuclear matrix, binds with the nucleic acid bases and reduce oxidative DNA damage in prostate epithelial cells [57].

Quercetin: Quercetin a potent antioxidant flavonoid has shown many health benefits including cancer prevention and treatment [58-60]. Quercetin prevented N-nitrosodiethylamine (NDEA)-induced lung tumorigenesis in mice [61]. Quercetin also prevented early stages of azoxymethane induced colorectal carcinogenesis [62]. Further studies showed preventive effects of Quercetin against NDEA induced hepatocellular carcinoma by inhibiting DNA specific mutations [63]. Quercetin protected Caco-2 and Hep G2 cells against $\mathrm{H} 2 \mathrm{O} 2$-induced DNA damage [64]. Quercetin also protected against Benzo[a]pyreneinduced DNA damage and pulmonary precancerous pathologic changes in mice through inhibition of cytochrome P4501A1 activity [65]. Further study showed that quercetin can inhibit ROS formation and the formation of strand breaks in PC12 neuronal cells [66]. A recent study suggested that quercetin can interact with DNA and inhibits tumor growth by cell cycle arrest and induction of mitochondrial pathway of apoptosis [67].

Genistein: Genistein is a natural flavonoid which acts as phyestrogen [68]. Dietary Genistein has shown chemoprotective properties against mammary and prostate cancers by modulating specific receptors and growth factor signaling pathways such as androgen receptor, estrogen receptor-alpha, progesterone receptor, epidermal growth factor receptor, insulin-like growth factor-I, and extracellular signal-regulated kinase-1 [69]. DNA damage protective properties are also reported. Genistein inhibited DMBA initiated and TPA promoted skin carcinogenesis in mice [70]. Genistein significantly inhibited DMBA-induced bulky DNA adduct formation while TPAinduced ornithine decarboxylase activity was moderately inhibited. Later, the photoprotective effects of Genistein were found using human reconstituted skin. Genistein inhibited UVB-induced pyrimidine dimer formation and preserved cutaneous proliferation and repair mechanisms [71]. Genistein also prevented DMBA induced mammary tumors [72]. And N-methyl-N-nitrosourea induced endometrial carcinogenesis [73]. Genistein protected calf thymus DNA against UV radiation or Fenton reaction system induced damage by inhibiting 8hydroxy-2'-deoxyguanosine (8-OHdG) formation [74].

Genistein also protected LAPC-4 prostate cells from hydrogen peroxide-induced DNA damage through induction of three genes with antioxidant activities, namely glutathione reductase, microsomal glutathione S-transferase 1 and metallothionein $1 \mathrm{X}$, at 1-30 microM genistein [75]. In breast cancer cells, genistein depleted the G1 population of cells and increased the accumulation of cells at G2. Few cells showed chromosome abnormalities and some cells showed polyploidy, which lead to increased cell death through activation of DNA damage response. Also Brcal mutant cells were found to be more sensitive to genistein [76].

Luteolin: Anticancer properties of Luteolin are well documented [77] few studies have also shown its role in carcinogenesis initiation preventive. Luteolin protected from 2-dimethyl hydrazine (DMH) and azoxymethane-induced colon carcinogenesis [78,79]. Luteolin inhibited formation of 8-hydroxy-2'-deoxyguanosine (8-OHdG) induced by either UV or Fenton reaction in calf thymus DNA and reduced oxidative DNA damage by reducing free radical hydrogen peroxide and superoxide anion (O2-) [35]. Luteolin also inhibited ROS and prevented DNA damage in PC12 neuronal cells [66].

Luteolin was also reported to increase repair activity in Caco- 2 cells [80]. Luteolin also inhibited UVB-induced human skin damage, erythema and the upregulation of cyclooxygenase- 2 and prostaglandin $\mathrm{E}_{2}$ production via MAPK pathway [81].

Rutin: Rutin has shown promosing results in the treatment of various diseases including cancer $[82,83]$. Rutin also protects DNA against damage. Rutin protected against hepatocarcinogens aflatoxin $\mathrm{B} 1$ and $\mathrm{N}$-nitrosodimethylamine induced single-strand breaks in nuclear Rutin also reduced induction of repair enzymes polymerase, DNA polymerase beta and DNA ligase [84]. Rutin also protected against hydrogen peroxide induced DNA damage in Caco-2 and HepG2 cells [64]. Flavonoids, quercetin and rutin, protected Caco-2 cells against tert-butylhydroperoxide and menadione-induced DNA single strand breaks by their metal ion chelating ability [85].

Naringenin: Naringin is found in grapes and citrus fruit and and have shown promising results in the treatment of obesity, metabolic disorders [86] and its anti-cancer and chemo-sensitizing properties are also reported [87-89]. For instance, Naringenin inhibited azoxymethane induced colon carcinogenesis and lowered the number of high multiplicity aberrant foci [90]. Moreover, Naringenin protected plasmid DNA from UVB-induced DNA damage [91]. Naringenin also protected against alloxan-induced DNA-damage in the peripheral lymphocytes of diabetic mice [92].

Morin: Morin is obtained from figs and other Moraceae have shown anti-oxidant [93] and anti-cancer properties [94]. For instance, Morin inhibited azoxymethane-induced bowl tumorigenesis [95] and 4nitroquinoline 1-oxide (4-NQO)-induced tongue tumorigenesis and PCNA index in rats [96] and also protected from NDEA induced hepatocellular [97]. Furthermore, Morin inhibited cancer progression in breast cancer cells MDA-MB-231 [98] and protected against hydrogen peroxide induced DNA-damage by inhibiting DNA strand breaks, 8-OHdG formation and decrease of nuclear phospho histone H2AX expression [99]. Morin also protected rat hepatocytes DNA from high glucose induced DNA fragmentation, chromatin condensation and hypodiploid DNA [100] and was also observed to protect against gamma-radiation induced oxidative DNA damage by 
attenuation of SEK1-JNK-AP-1 pathway [101]. These studies strongly suggest the therapeutic potential of flavonoids not only in cancer therapy but also in cancer initiation and DNA damage prevention (Figure 2).

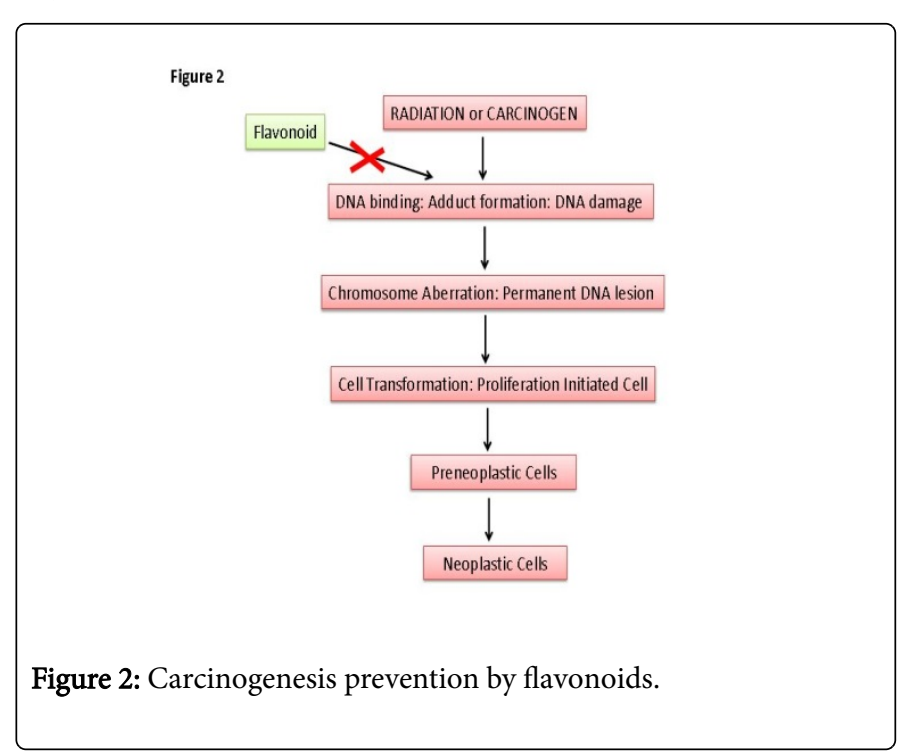

\section{Concluding Remarks}

Flavonoids have shown promising results in protection against various DNA damaging agents, especially since they have antioxidant properties and they can also modulate DNA damage and repair pathways. These effects of flavonoids may therefore, contribute to their anti-carcinogenic effects. In general these properties cannot be used for apoptosis induction in cancer cells. Flavonoids can be useful in the prevention of carcinogenesis by protecting DNA damage and inducing repair pathways. However their carcinogenesis preventive properties cannot be solely linked to DNA damage protection as they also regulate many other important cellular events such as cell cycle and apoptosis. Though flavonoids show excellent health benefits and anticancer properties, more studies are needed before their use in therapy. Flavonoids can be bio transformed into more harmful genotoxic agents and purified compounds may have toxicity and solubility issues. These aspects should be carefully considered before their use in therapy.

\section{Acknowledgement}

Prabha Tiwari is supported by the postdoctoral fellowship from the Tokyo Biochemical Research Foundation, Japan. No explicit funding was necessitated for this study.

\section{References}

1. Federico A, Morgillo F, Tuccillo C, Ciardiello F, Loguercio C (2007) Chronic inflammation and oxidative stress in human carcinogenesis. Int $\mathrm{J}$ Cancer 121: 2381-2386.

2. Kryston TB, Georgiev AB, Pissis P, Georgakilas AG (2011) Role of oxidative stress and DNA damage in human carcinogenesis. Mutat Res 711: 193-201.

3. Nobili S, Lippi D, Witort E, Donnini M, Bausi L, et al. (2009) Natural compounds for cancer treatment and prevention. Pharmacol Res 59: 365-378.
4. Chahar MK, Sharma N, Dobhal MP, Joshi YC (2011) Flavonoids: A versatile source of anticancer drugs. Pharmacogn Rev 5: 1-12.

5. Azqueta A, Collins A (2016) Polyphenols and DNA Damage: A Mixed Blessing. Nutrients 8: 25.

6. Motalleb G, Sanadgol N, Estakhr J, Shahraki E (2012) Methods for DNA Strand Breaks Detection. Res J Appl Sci Eng Technol 4: 1888-1894.

7. Nikitaki Z, Hellweg CE, Georgakilas AG, Ravanat JL (2015) Stressinduced DNA damage biomarkers: applications and limitations. Front Chem 3: 35.

8. Williams RJ, Spencer JP, Rice-Evans C (2004) Flavonoids: antioxidants or signalling molecules? Free Radic Biol Med 36: 838-49.

9. Helleday T, Eshtad S, Nik-Zainal S (2014) Mechanisms underlying mutational signatures in human cancers. Nat Rev Genet 15: 585-598.

10. Jackson SP, Bartek J (2009) The DNA-damage response in human biology and disease. Nature 461: 1071-1078.

11. Poirier MC (2012) Chemical-induced DNA damage and human cancer risk. Discov Med 14: 283-288.

12. Friedberg EC, McDaniel LD, Schultz RA (2004) The role of endogenous and exogenous DNA damage and mutagenesis. Curr Opin Genet Dev 14: 5-10.

13. Lomax ME, Folkes LK, O'Neill P (2013) Biological consequences of radiation-induced DNA damage: relevance to radiotherapy. Clin Oncol (R Coll Radiol) 25: 578-585.

14. Bi X (2015) Mechanism of DNA damage tolerance. World J Biol Chem 6: 48-56.

15. Ferreyra ML, Rius SP, Casati P (2012) Flavonoids: biosynthesis, biological functions, and biotechnological applications. Front Plant Sci 3: 222.

16. Lago JH, Toledo-Arruda AC, Mernak M, Barrosa KH, Martins MA, et al. (2014) Structure-activity association of flavonoids in lung diseases. Molecules 19: 3570-3395.

17. Fang Y, Lu Y, Zang X, Wu T, Qi X, et al. (2016) 3D-QSAR and docking studies of flavonoids as potent Escherichia coli inhibitors. Sci Rep 6: 23634.

18. Malaveille C, Hautefeuille A, Pignatelli B, Talaska G, Vineis P, et al. (1996) Dietary phenolics as anti-mutagens and inhibitors of tobacco-related DNA adduction in the urothelium of smokers. Carcinogenesis 17: 2193-200.

19. Hollman PC, Katan MB (1999) Dietary flavonoids: intake, health effects and bioavailability. Food Chem Toxicol 37: 937-942.

20. McCullough ML, Peterson JJ, Patel R, Jacques PF, Shah R, et al. (2012) Flavonoid intake and cardiovascular disease mortality in a prospective cohort of US adults. Am J Clin Nutr 95: 454-464.

21. Batra P, Sharma AK (2013) Anti-cancer potential of flavonoids: recent trends and future perspectives. Biotech 3: 439-459.

22. Filingeri V, Buonomo O, Sforza D (2014) Use of Flavonoids for the treatment of symptoms after hemorrhoidectomy with radiofrequency scalpel. Eur Rev Med Pharmacol Sci 18: 612-616.

23. Kumar S, Pandey AK (2013) Chemistry and biological activities of flavonoids: an overview. Scientific World J 2013: 162750.

24. Yao LH, Jiang YM, Shi J, Tomas-Barberan FA, Datta N, et al. (2004) Flavonoids in food and their health benefits. Plant Foods Hum Nutr 59: 113-122.

25. Agati G, Tattini M (2010) Multiple functional roles of flavonoids in photoprotection. New Phytol 186: 786-793.

26. Stapleton AE, Walbot V (1994) Flavonoids can protect maize DNA from the induction of ultraviolet radiation damage. Plant Physiol 105: 881-889.

27. Cao G, Sofic E, Prior RL (1997) Antioxidant and prooxidant behavior of flavonoids: structure-activity relationships. Free Radic Biol Med 22: 749-760.

28. Prochazkova D, Bousova I, Wilhelmova N (2011) Antioxidant and prooxidant properties of flavonoids. Fitoterapia 82: 513-523.

29. Sahu SC, Gray GC (1994) Kaempferol-induced nuclear DNA damage and lipid peroxidation. Cancer Lett 85: 159-64. 
Page 5 of 6

30. Hardigree AA, Epler JL (1978) Comparative mutagenesis of plant flavonoids in microbial systems. Mutat Res 58: 231-239.

31. MacGregor JT, Jurd L (1978) Mutagenicity of plant flavonoids: structural requirements for mutagenic activity in Salmonella typhimurium. Mutat Res 54: 297-309.

32. Resende FA, Vilegas W, Dos Santos LC, Varanda EA (2012) Mutagenicity of flavonoids assayed by bacterial reverse mutation (Ames) test. Molecules 17: 5255-5268.

33. Oikawa S, Furukawaa A, Asada H, Hirakawa K, Kawanishi S (2003) Catechins induce oxidative damage to cellular and isolated DNA through the generation of reactive oxygen species. Free Radic Res 37: 881-890.

34. Tsai YC, Wang YH, Liou CC, Lin YC, Huang H, et al. (2012) Induction of oxidative DNA damage by flavonoids of propolis: its mechanism and implication about antioxidant capacity. Chem Res Toxicol 25: 191-196.

35. Cai Q, Rahn RO, Zhang R (1997) Dietary flavonoids, quercetin, luteolin and genistein, reduce oxidative DNA damage and lipid peroxidation and quench free radicals. Cancer Lett 119: 99-107.

36. Rusak G, Piantanida I, Masic L, Kapuralin K, Durgo K, et al. (2010) Spectrophotometric analysis of flavonoid-DNA interactions and DNA damaging/protecting and cytotoxic potential of flavonoids in human peripheral blood lymphocytes. Chem Biol Interact 188: 181-189.

37. Kanakis CD, Tarantilis PA, Polissiou MG, Tajmir-Riahi HA (2006) Interaction of antioxidant flavonoids with tRNA: intercalation or externa binding and comparison with flavonoid-DNA adducts. DNA Cell Biol 25: 116-23.

38. Kanakis CD, Tarantilis PA, Polissiou MG, Diamantoglou S, Tajmir-Riahi HA (2005) DNA interaction with naturally occurring antioxidant flavonoids quercetin, kaempferol, and delphinidin. J Biomol Struct Dyn 22: 719-724.

39. Bi S, Qiao C, Song D, Tian Y, Gao D, et al. (2006) Study of interactions of flavonoids with DNA using acridine orange as a fluorescence probe. Sensors and Actuators B: Chemical 119: 199-208.

40. Hegde AH, Prashanth SN, Seetharamappa J (2012) Interaction of antioxidant flavonoids with calf thymus DNA analyzed by spectroscopic and electrochemical methods. J Pharm Biomed Anal 63: 40-46.

41. Tawani A, Kumar A (2015) Structural Insight into the interaction of Flavonoids with Human Telomeric Sequence. Sci Rep 5: 17574.

42. Tiwari P, Kumar A, Ali M, Mishra KP (2010) Radioprotection of plasmid and cellular DNA and Swiss mice by silibinin. Mutat Res 695: 55-60.

43. Tiwari P, Kumar A, Balakrishnan S, Kushwaha HS, Mishra KP (2011) Silibinin-induced apoptosis in MCF7 and T47D human breast carcinoma cells involves caspase-8 activation and mitochondrial pathway. Cancer Invest 29: 12-20.

44. Tiwari P, Mishra KP (2015) Silibinin in cancer therapy: A promising prospect. Cancer Res Front 1: 303-318.

45. Bhatia N, Zhao J, Wolf DM, Agarwal R (1999) Inhibition of human carcinoma cell growth and DNA synthesis by silibinin, an active constituent of milk thistle: comparison with silymarin. Cancer Lett 147: 77-84.

46. Singh RP, Raina K, Deep G, Chan D, Agarwal R (2009) Silibinin suppresses growth of human prostate carcinoma PC-3 orthotopic xenograft via activation of extracellular signal-regulated kinase $1 / 2$ and inhibition of signal transducers and activators of transcription signaling. Clin Cancer Res 15: 613-621.

47. Narayanapillai S, Agarwal C, Deep G, Agarwal R (2014) Silibinin inhibits ultraviolet $\mathrm{B}$ radiation-induced DNA-damage and apoptosis by enhancing interleukin-12 expression in JB6 cells and SKH-1 hairless mouse skin. Mol Carcinog 53: 471-479.

48. Ravichandran K, Velmurugan B, Gu M, Singh RP, Agarwal R (2010) Inhibitory effect of silibinin against azoxymethane-induced colon tumorigenesis in A/J mice. Clin Cancer Res 16: 4595-4606.

49. Sangeetha N, Felix AJ, Nalini N (2009) Silibinin modulates biotransforming microbial enzymes and prevents 1,2-dimethylhydrazineinduced preneoplastic changes in experimental colon cancer. Eur J Cancer Prev 18: 385-394.
50. Velmurugan B, Singh RP, Tyagi A, Agarwal R (2008) Inhibition of azoxymethane-induced colonic aberrant crypt foci formation by silibinin in male Fisher 344 rats. Cancer Prev Res (Phila) 1: 376-384.

51. Raina K, Kumar S, Dhar D, Agarwal R (2016) Silibinin and colorectal cancer chemoprevention: a comprehensive review on mechanisms and efficacy. J Biomed Res 30: 452-465.

52. Rajamanickam S, Velmurugan B, Kaur M, Singh RP, Agarwal R (2010) Chemoprevention of intestinal tumorigenesis in APCmin/+ mice by silibinin. Cancer Res 70: 2368-2378.

53. Choudhury D, Ganguli A, Dastidar DG, Acharya BR, Das A, et al. (2013) Apigenin shows synergistic anticancer activity with curcumin by binding at different sites of tubulin. Biochimie 95: 1297-1309.

54. Xu Y, Xin Y, Diao Y, Lu C, Fu J, et al. (2011) Synergistic effects of apigenin and paclitaxel on apoptosis of cancer cells. PLoS One 6: e29169.

55. Wei H, Tye L, Bresnick E, Birt DF (1990) Inhibitory effect of apigenin, a plant flavonoid, on epidermal ornithine decarboxylase and skin tumor promotion in mice. Cancer Res 50: 499-502.

56. Das S, Das J, Paul A, Samadder A, Khuda-Bukhsh AR (2013) Apigenin, a bioactive flavonoid from Lycopodium clavatum, stimulates nucleotide excision repair genes to protect skin keratinocytes from ultraviolet Binduced reactive oxygen species and DNA damage. J Acupunct Meridian Stud 6: 252-262.

57. Sharma H, Kanwal R, Bhaskaran N, Gupta S (2014) Plant flavone apigenin binds to nucleic acid bases and reduces oxidative DNA damage in prostate epithelial cells. PLoS One 9: e91588.

58. Bischoff SC (2008) Quercetin: potentials in the prevention and therapy of disease. Curr Opin Clin Nutr Metab Care 11: 733-740.

59. Chirumbolo $S$ (2013) Quercetin in cancer prevention and therapy. Integr Cancer Ther 12: 97-102.

60. Russo M, Spagnuolo C, Tedesco I, Bilotto S, Russo GL (2012) The flavonoid quercetin in disease prevention and therapy: facts and fancies. Biochem Pharmacol 83: 6-15.

61. Khanduja KL, Gandhi RK, Pathania V, Syal N (1999) Prevention of Nnitrosodiethylamine-induced lung tumorigenesis by ellagic acid and quercetin in mice. Food Chem Toxicol 37: 313-318.

62. Yang K, Lamprecht SA, Liu Y, Shinozaki H, Fan K, et al. (2000) Chemoprevention studies of the flavonoids quercetin and rutin in normal and azoxymethane-treated mouse colon. Carcinogenesis 21: 1655-1660.

63. Seufi AM, Ibrahim SS, Elmaghraby TK, Hafez EE (2009) Preventive effect of the flavonoid, quercetin, on hepatic cancer in rats via oxidant/ antioxidant activity: molecular and histological evidences. J Exp Clin Cancer Res 28: 80

64. Aherne SA, O'Brien NM (1999) Protection by the flavonoids myricetin, quercetin, and rutin against hydrogen peroxide-induced DNA damage in Caco-2 and Hep G2 cells. Nutr Cancer 34: 160-166.

65. Jin NZ, Zhu YP, Zhou JW, Mao L, Zhao RC, et al. (2006) Preventive effects of quercetin against benzo[a]pyrene-induced DNA damages and pulmonary precancerous pathologic changes in mice. Basic Clin Pharmacol Toxicol 98: 593-598.

66. Silva JP, Gomes AC, Coutinho OP (2008) Oxidative DNA damage protection and repair by polyphenolic compounds in PC12 cells. Eur J Pharmacol 601: 50-60.

67. Srivastava S, Somasagara RR, Hegde M, Nishana M, Tadi SK, et al. (2016) Quercetin, a Natural Flavonoid Interacts with DNA, Arrests Cell Cycle and Causes Tumor Regression by Activating Mitochondrial Pathway of Apoptosis. Sci Rep 6: 24049.

68. Patisaul HB, Jefferson W (2010) The pros and cons of phytoestrogens. Front Neuroendocrinol 31: 400-419.

69. Lamartiniere CA, Cotroneo MS, Fritz WA, Wang J, Mentor-Marcel R, et al. (2002) Genistein chemoprevention: timing and mechanisms of action in murine mammary and prostate. J Nutr 132: 552S-558S.

70. Wei H, Bowen R, Zhang X, Lebwohl M (1998) Isoflavone genistein inhibits the initiation and promotion of two-stage skin carcinogenesis in mice. Carcinogenesis 19: 1509-1514. 
71. Moore JO, Wang Y, Stebbins WG, Gao D, Zhou X, et al. (2006) Photoprotective effect of isoflavone genistein on ultraviolet B-induced pyrimidine dimer formation and PCNA expression in human reconstituted skin and its implications in dermatology and prevention of cutaneous carcinogenesis. Carcinogenesis 27: 1627-1635.

72. Fritz WA, Coward L, Wang J, Lamartiniere CA (1998) Dietary genistein: perinatal mammary cancer prevention, bioavailability and toxicity testing in the rat. Carcinogenesis 19: 2151-2158.

73. Lian Z, Niwa K, Tagami K, Hashimoto M, Gao J, et al. (2001) Preventive effects of isoflavones, genistein and daidzein, on estradiol-17beta-related endometrial carcinogenesis in mice. Jpn J Cancer Res 92: 726-734.

74. Wei H, Cai Q, Rahn RO (1996) Inhibition of UV light- and Fenton reaction-induced oxidative DNA damage by the soybean isoflavone genistein. Carcinogenesis 17: 73-77.

75. Raschke M, Rowland IR, Magee PJ, Pool-Zobel BL (2006) Genistein protects prostate cells against hydrogen peroxide-induced DNA damage and induces expression of genes involved in the defence against oxidative stress. Carcinogenesis 27: 2322-2330.

76. Tominaga Y, Wang A, Wang RH, Wang X, Cao L, et al. (2007) Genistein inhibits Brcal mutant tumor growth through activation of DNA damage checkpoints, cell cycle arrest, and mitotic catastrophe. Cell Death Differ 14: $472-479$.

77. Lin Y, Shi R, Wang X, Shen HM (2008) Luteolin, a flavonoid with potential for cancer prevention and therapy. Curr Cancer Drug Targets 8: 634-646.

78. Manju V, Nalini N (2007) Protective role of luteolin in 1,2dimethylhydrazine induced experimental colon carcinogenesis. Cell Biochem Funct 25: 189-194.

79. Pandurangan AK, Kumar SA, Dharmalingam P, Ganapasam S (2014) Luteolin, a bioflavonoid inhibits azoxymethane-induced colon carcinogenesis: Involvement of iNOS and COX-2. Pharmacogn Mag 10: S306-10.

80. Ramos AA, Pereira-Wilson C, Collins AR (2010) Protective effects of ursolic acid and luteolin against oxidative DNA damage include enhancement of DNA repair in Caco-2 cells. Mutat Res 692: 6-11.

81. Wolfle U, Esser PR, Simon-Haarhaus B, Martin SF, Lademann J, et al. (2011) UVB-induced DNA damage, generation of reactive oxygen species, and inflammation are effectively attenuated by the flavonoid luteolin in vitro and in vivo. Free Radic Biol Med 50: 1081-1093.

82. Al-Dhabi NA, Arasu MV, Park CH, Park SU (2015) An up-to-date review of rutin and its biological and pharmacological activities. EXCLI J 14: 59-63.

83. Perk AA, Shatynska-Mytsyk I, Gercek YC, Boztas K, Yazgan M, et al. (2014) Rutin mediated targeting of signaling machinery in cancer cells. Cancer Cell Int 14: 124.

84. Webster RP, Gawde MD, Bhattacharya RK (1996) Protective effect of rutin, a flavonol glycoside, on the carcinogen-induced DNA damage and repair enzymes in rats. Cancer Lett 109: 185-191.

85. Aherne SA, O'Brien NM (2000) Mechanism of protection by the flavonoids, quercetin and rutin, against tert-butylhydroperoxide- and menadione-induced DNA single strand breaks in Caco- 2 cells. Free Radic Biol Med 29: 507-514.

86. Alam MA, Subhan N, Rahman MM, Uddin SJ, Reza HM, et al. (2014) Effect of citrus flavonoids, naringin and naringenin, on metabolic syndrome and their mechanisms of action. Adv Nutr 5: 404-417.
87. Abaza MS, Orabi KY, Al-Quattan E, Al-Attiyah RJ (2015) Growth inhibitory and chemo-sensitization effects of naringenin, a natural flavanone purified from Thymus vulgaris, on human breast and colorectal cancer. Cancer Cell Int 15: 46.

88. Ahamad MS, Siddiqui S, Jafri A, Ahmad S, Afzal M, et al. (2014) Induction of apoptosis and antiproliferative activity of naringenin in human epidermoid carcinoma cell through ROS generation and cell cycle arrest. PLoS One 9: e110003.

89. Bao L, Liu F, Guo HB, Li Y, Tan BB, et al. (2016) Naringenin inhibits proliferation, migration, and invasion as well as induces apoptosis of gastric cancer SGC7901 cell line by downregulation of AKT pathway. Tumour Biol 37: 11365-11374.

90. Leonardi T, Vanamala J, Taddeo SS, Davidson LA, Murphy ME, et al. (2010) Apigenin and naringenin suppress colon carcinogenesis through the aberrant crypt stage in azoxymethane-treated rats. Exp Biol Med (Maywood) 235: 710-717.

91. Kootstra A (1994) Protection from UV-B-induced DNA damage by flavonoids. Plant Mol Biol 26: 771-774.

92. Orsolic N, Gajski G, Garaj-Vrhovac V, Dikic D, Prskalo ZS, et al. (2011) DNA-protective effects of quercetin or naringenin in alloxan-induced diabetic mice. Eur J Pharmacol 656: 110-8.

93. Subash S, Subramanian P (2009) Morin a flavonoid exerts antioxidant potential in chronic hyperammonemic rats: a biochemical and histopathological study. Mol Cell Biochem 327: 153-161.

94. Hyun HB, Lee WS, Go SI, Nagappan A, Park C, et al. (2015) The flavonoid morin from Moraceae induces apoptosis by modulation of Bcl-2 family members and Fas receptor in HCT 116 cells. Int J Oncol 46: 2670-2678.

95. Tanaka T, Kawabata K, Kakumoto M, Makita H, Ushida J, et al. (1999) Modifying effects of a flavonoid morin on azoxymethane-induced large bowel tumorigenesis in rats. Carcinogenesis 20: 1477-1484.

96. Kawabata K, Tanaka T, Honjo S, Kakumoto M, Hara A, et al. (1999) Chemopreventive effect of dietary flavonoid morin on chemically induced rat tongue carcinogenesis. Int J Cancer 83: 381-386.

97. Sivaramakrishnan V, Shilpa PN, Praveen Kumar VR, Niranjali Devaraj S (2008) Attenuation of N-nitrosodiethylamine-induced hepatocellular carcinogenesis by a novel flavonol-Morin. Chem Biol Interact 171: 79-88.

98. Jin H, Lee WS, Eun SY, Jung JH, Park HS, et al. (2014) Morin, a flavonoid from Moraceae, suppresses growth and invasion of the highly metastatic breast cancer cell line MDA-MB231 partly through suppression of the Akt pathway. Int J Oncol 45: 1629-37.

99. Zhang R, Kang KA, Piao MJ, Maeng YH, Lee KH, et al. (2009) Cellular protection of morin against the oxidative stress induced by hydrogen peroxide. Chem Biol Interact 177: 21-27.

100. Kapoor R, Kakkar P (2012) Protective role of morin, a flavonoid, against high glucose induced oxidative stress mediated apoptosis in primary rat hepatocytes. PLoS One 7: e41663.

101. Zhang R, Kang KA, Kang SS, Park JW, Hyun JW (2011) Morin (2',3,4',5,7pentahydroxyflavone) protected cells against gamma-radiation-induced oxidative stress. Basic Clin Pharmacol Toxicol 108: 63-72. 